\title{
A Study on Effectiveness of the Crop Insurance in Karnataka -With Special Reference Chikmagalur District
}

\author{
Hamsini H.P \\ Final Year Student \\ Ramaiah University of Applied Sciences \\ Bangalore-560054, India \\ E-mail: hamsinigowdaI3@gmail.com \\ Rashmi.R \\ Professor \\ Faculty of Management and Commerce \\ Ramaiah University of Applied Sciences \\ Bangalore-560 054, India \\ E-mail: rashmi.co.mc@msruas.ac.in
}

\begin{abstract}
Indian agriculture activities are severely dependent on rainfall that occurs in monsoon year. The behavior of the monsoon is unusual that cause natural disasters like lack of rainfall or floods, cyclones, etc. Majority of the cropped area is affected by drought. About I 2 million hectors of the agricultural land is affected by the calamities and this land does not have irrigation facility. Crop insurance is a tool to protect the farmers from financial loss as a result of crop loss out of nearly all natural factors past their manage consisting of weather, natural calamities, floods, pests, illnesses etc. There is a need for the crop insurance to protect the farmers against the financial loss due to crop loss. There are various schemes under crop insurance which aim to provide financial support to farmers. This is the motivation behind the study. The research is carried out to understand the effectiveness of crop insurance. A sample of 348 Farmers was considered to collect opinions through a structured questionnaire in Chikmaglur district, Karnataka. The factors under the study were Awareness, Financial security, income stability, Loan repayment towards the future acceptance of crop insurance
\end{abstract}

Keywords: Crop insurance, Awareness, Financial security, income stability, Loan repayment, Future acceptance

\section{Introduction}

Crop insurance is one of the several types of insurance which are provided to the farmers. This coverage is given to the agriculturists and farmers. This Crop coverage policy has been given since the time of Kharif I985.Insurance gives economic help for loss control in agriculture. This coverage provide protection scheme for the farmers whose vegetation get damaged at some point of natural disaster.

The loss is suffered because of natural calamities is given protection by the government of India. It is to be stated that the insurance covers the insured crop. The crop insurance does not provide insurance cover for multiple vegetation. Experimental Crop coverage policy is obtainable to the medium farmers. Many farmers are protected underneath this insurance policy. This scheme provides financial security to the farmers. Crop insurance makes up the loss or harm to developing plants as a consequence of a selection of causes which includes drought, flood and disorder. The cultivators pay a premium and protection is given to them at the equal basis as in other coverage. Whilst the production from an insured acreage falls under the insured insurance, the risk is entitled to an indemnity.

\section{Literature Review}

The study reviewed the provisions, performance and improvements in Pradhan Mantri Fasal Bima Yojana scheme. PMFBY was compared with NAIS and was found that PMBFY benefited more to farmers with low premium rate, covered majority of the risk and they used technology for the settlements (Mahatma Jyothi Rao Phoole, 2017). The study was conducted to know the better scheme in Andhra Pradesh and it was found that more number of farmers was benefited under weather based crop insurance scheme (Karthick (2016). The other study evaluate the mass acceptance of NAIS under control of AIC of India among loanee and non-loanee farmers. The study showed $40 \%$ of the Loanee farmers were unaware of compulsory insurance benefit of NAIS scheme (Avik Challoadhaya 2016). Examine and associate indicators with their coverage, financial performance 
and operational efficiency that provide safety for the farmers. He finds that WBCIS WBCIS performance better than NAIS because of the higher adoption rate, higher percentage of the farmers are benefited, lower premium (Mamatha Swain 2015). Elicit the issues and challenges of agricultural insurance in India. It was found that there was an issue relating to operations ,governance and financial sustainability. NAIS scheme only covers sowing risk, post harvesting losses are not covered (Shathabonia Raju 2015). Paper has studied the structures and concert of National Agricultural Insurance Scheme (NAIS) working in the country and has optional some alterations to make it more operative. National Agricultural Insurance Scheme has served very limited purpose. The coverage in terms of area, number of agriculturalists and worth of farming production is very lesser, sum of indemnity, created on area approach, miss affected the farmers outside the compensated area, and many of the other policy are also not feasible (S.S. Raju, 2015).

\section{Objectives of the Study}

- To study the currently available crop insurance schemes and challenges in crop insurance

- To study the performance of the crop insurance in chickmaglur district

- To study acceptance of crop insurance amongst the loanee and non-loanee farmers.

- To study the problems faced by farmers in crop insurance and provide suitable suggestions

\section{Database and Methodology}

Data Collection: The present study is conducted to understand and know the importance of crop insurance and the factors which are affecting towards acceptance of crop insurance. The analysis is conducted using primary data collected from the farmers and descriptive statistics is used to derive results. For this research a total of 348 Farmer's in Chikmaglur district have been collected.

Primary data: Questionnaire survey was done to collect the opinions of farmers in chickmagalur district. Obtained data was analyzed using SPSS statistical software to examine the relationship among the identified factors.

Secondary data: This data is collected through Literature reviews, Websites and books

\section{Results and Discussion}

Table I: Showing Reliability statistics

\begin{tabular}{lll}
\hline Cronbach's Alpha & Cronbach's Alpha Based on Standardized Items & N of Items \\
\hline .806 & $.86 \mathrm{I}$ & 23 \\
\hline
\end{tabular}

Table I measure the questionnaires consistency Cronbach's $\alpha$ was used. The complete coefficient was found to be 0.806 which outstrips the marginal approvals i.e., 0.70 . Hence, the sustainability and strength of the implement is reasoned to be good.

\section{I Hypothesis}

$\mathrm{H}_{0}$ : Satisfaction, Financial security, Income stability loan repayment has no significant impact in Future acceptance of crop insurance

$\mathrm{H}_{1}$ : Satisfaction has a significant impact on Future acceptance of crop insurance

$\mathrm{H}_{2}$ : Income stability has a significant impact on Future acceptance of crop insurance

$\mathrm{H}_{3}$ : Financial security has a significant impact on Future acceptance of crop insurance

$\mathrm{H}_{4}$ : loan repayment has a significant impact on Future acceptance of crop insurance

\subsection{Correlations}

\begin{tabular}{|c|c|c|c|c|c|c|}
\hline \multicolumn{7}{|c|}{$\begin{array}{l}\text { Table 2: showing Correlations between Future acceptance and Loan Repayment satisfaction } \\
\text { Income stability }\end{array}$} \\
\hline & & Future acceptance & $\begin{array}{l}\text { Loan } \\
\text { Repayment }\end{array}$ & Satisfaction & Financial security & Income stablity \\
\hline \multirow[t]{3}{*}{ Future acceptance } & $\begin{array}{l}\text { Pearson } \\
\text { Correlation }\end{array}$ & $\mathrm{I}$ & $.510^{+s+x}$ & $.780^{4+s}$ & $.705^{\text {sta }}$ & $.722^{*+s}$ \\
\hline & Sig. (2-tailed) & & .000 & .000 & .000 & .000 \\
\hline & $\mathrm{N}$ & 348 & 348 & 348 & 348 & 348 \\
\hline
\end{tabular}

In Table 2 correlation results reveal that there is a positive relation between financial security, Loan Repayment Satisfaction, income stability and Future Acceptance. As we can see that the correlation coefficient is $0.510,0.780,0.705,0.722$ between financial security, Loan Repayment Satisfaction, income stability and Future Acceptance respectively at of 0.0I level of significance of financial security and Future Acceptance. 


\subsection{Regression}

Table 3: Showing regression Model Summary

\begin{tabular}{lllll}
\hline Model & R & R Square & Adjusted R Square & Std. Error of the Estimate \\
\hline $\mathrm{I}$ & $.824^{\mathrm{a}}$ & .679 & .675 & .475 \\
\hline
\end{tabular}

Table 4: Showing regression coefficient

\begin{tabular}{|c|c|c|c|c|c|c|}
\hline \multicolumn{2}{|c|}{ Model } & \multicolumn{2}{|c|}{ Unstandardized Coefficients } & \multirow{2}{*}{$\begin{array}{l}\text { Standardized } \\
\text { Coefficients } \\
\text { Beta }\end{array}$} & \multirow[t]{2}{*}{$\mathrm{T}$} & \multirow[t]{2}{*}{ Sig. } \\
\hline & & $\mathrm{B}$ & Std. Error & & & \\
\hline \multirow[t]{5}{*}{$\mathrm{I}$} & (Constant) & .156 & .078 & & 2.014 & .045 \\
\hline & Income stability & .139 & .085 &. $\mathrm{I} 2 \mathrm{I}$ & 1.628 & .104 \\
\hline & Financial security & .258 & .074 & .235 & 3.469 & .001 \\
\hline & Satisfaction & .487 & .042 & .518 & II.657 & .000 \\
\hline & Loan Repayment & .039 & .035 & .042 & I.I08 & .269 \\
\hline
\end{tabular}

a. Dependent Variable: Future acceptance

Table 3 and 4 shows that the model is capable of explaining $67.9 \%$ of the impact of future acceptance of crop insurance by independent variables such as satisfaction, financial security, and Income stability loan repayment. This is from the evidence that the Adjusted R Square is 0.679 , which also means that remaining $32.1 \%$ on future acceptance will happen by the factors that are not included in the model.

In order to study Future acceptance of crop insurance in chikmaglur district, correlation and regression analysis is been conducted. From the results it is concluded that there is a relationship between Future acceptance, Satisfaction, Financial security, Income stability. This makes us reject the null hypothesis $H_{0}$. That is the statement "Satisfaction, Financial security, Income stability has no significance in Future acceptance of crop insurance." Is rejected. The results obtained show considered has a strong impact on Future acceptance of crop insurance which makes us accept the alternate hypothesis.

\subsection{Chi-Square Tests}

The Null Hypotheses H0: There is no significant influence of loan status on decision of taking crop insurance.

The alternative Hypothesis HI: There is significant influence of loan status on decision of taking crop insurance.

Table 5: showing chi-square test

\begin{tabular}{|c|c|c|c|c|c|}
\hline & Value & Df & $\begin{array}{l}\text { Asymptotic } \\
\text { Significance } \\
\text { (2-sided) }\end{array}$ & Exact Sig. (2-sided) & Exact Sig. (I-sided) \\
\hline Pearson Chi-Square & $10.566^{a}$ & $\mathrm{I}$ & .001 & & \\
\hline Likelihood Ratio & 8.688 & $\mathrm{I}$ & .003 & & \\
\hline Fisher's Exact Test & & & & .005 & .003 \\
\hline \multicolumn{6}{|c|}{ a. 0 cells $(0.0 \%)$ have expected count less than 5 . The minimum expected count is 5.43 . } \\
\hline b. Computed only for a $2 \times 2$ table & & & & & \\
\hline
\end{tabular}

Table 5 observes that Pearson Chi-Square value is 10.56 at I degree of freedom. The p value is 0.005 which is less than the alpha value 0.05 . Hence the it is significant.so we reject the null hypothesis i.e. H0: There is no significant influence of loan status on decision of taking crop insurance and accept the alternative hypothesis i.e. HI: There is significant influence of loan status on decision of taking crop insurance. . 0 cells $(.0 \%)$ have expected count less than 5.Cramer's v value represents the size of the effect .here the Cramer's value is .I74 which means there is a good effect on influence of loan status on decision of taking crop insurance.

6. Conclusion

The study revealed the farmers have taken crop loan depending on their income. It was found that loan status of the farmers influence the decision of taking crop insurance. The studies found that crop insurance have helped farmers in repayment of loan. 
The study found that crop insurance helps in stabilizing the income of the farmers. It was found that the pay out of the crop insurance is low and also more time is taken by the surveyors for assessment which delays the claim settlement. The premium of the (PMFBY) Pradhan Mantri Fasal Bima Yojana is comparatively more than (WBCIS)Weather based Crop Insurance Scheme (PMFBY) Pradhan Mantri Fasal Bima Yojana provides more benefits compared to any other schemes It was found that majority of the farmers were satisfied with the currently available crop insurance schemes and would suggest to their friends and relatives Crop insurance provides protection to farmers against crop loss.it helps farmers to repay their debts during the time of financial loss due to crop loss .it also provides replant security and preventive planting .crop insurance protects farmers form the financial loss due to pesticides and weather changes it acts as tool to farmers which helps farmers which helps farmers to manage their financial yield and yield loss. Insurance coverage conduct awareness programs and protects farmer's farm. National bank for agricultural and rural development and reserve bank of India must monitor the regulation regarding the compulsory cop insurance for loaned farmers. Financial institutions must settle the claims on time. The premium of MAINS must be reduced.

\section{References}

Avik ChattopadhayaI, Subrata Ray, Journal of advances in business management, Adoption of NAIS by Farmers to cope up with Agricultural Risk ,2(3),I54-I58,

Adivappar N, Aditya KS. (20I4). Status \& prospects of national agricultural insurance scheme in India. International Journal of Entrepreneurship \& Business Environment Perspectives, 3(I), 876-880.

Gurdev Singh. (2012). Crop Insurance in India, International Joumal of Advanced Research and Development.

Kumar FR, Breshnev. Current issues on crop insurance in cauvery delta region- an overview. International Journal of World Research, I(II), 73.

Karthick. (2016). An Inclusive Study on Agriculture Insurance Schemes in India ,Amity Journal of Agribusiness ,I(2),38-45.

Mahatma Jyothi Rao Phoole.(2017). To review the provisions and performance of crop insurance scheme in India.

Mamatha Swain.(2015).'To analyse and compare various indicators', South Asian Network for Development and Environmental Economics ,I04-I6.

Mahatma Jyothi Rao Phoole.(2017).To review the provisions and performance of crop insurance scheme in India.

Mohapatra L, Dhaliwal RK. (20I4). Review of agricultural insurance in Punjab state of India. International Joumal of Advanced Research, 2(5), 459-467.

Nair, R. (2010). "Crop Insurance in India: Changes and Challenges ”Economic and Political Weekly, February 6th: 19-22.

Pal D, Mondal T. (2010). Agricultural insurance in India: approaches and challenges. International Journal of Rural Studies, I7(I), I-7.

Olivier Mahul, World Bank Policy Research Working Paper 3654, July 2005.

Prasanna V. (20I4). Impact of monsoon rainfall on the total food grain yield over India; J. Earth Syst. Sci. I23(5),II29-II45.

Raju, S.S., R. Chand.(2008). Agricultural insurance in India: problems and prospects, ”Indian Council of Agricultural Research, New Delhi, NCAP working paper.

Raju SS, Ramesh C. (2008).A study on the performance of national agricultural insurance scheme and suggestions to make it more effective. Agricultural Economics Research Review, 2I, I I-I9.

Singh S. (2004).Crop insurance in India - a brief review. Journal of Indian Society of Agriculture Statistics, 57, 2 I 7-225.

Sreejamol k.s, sridevi k.b.(2018). Farmers behaviour and attitudes towards crop insurance scheme in India. Agricultural Economics Research Review, 2I, II-I9.

Sindhu Rs, Vatta k.(2012).Risk in Punjab Agriculture: current status and emerging issues.

Vandana Rathore.(2017). The performance of PMFBY and other crop insurance models in India, International Journal of Advanced Research and Development, 2(5),602-607.

\section{Copyrights}

Copyright for this article is retained by the author(s), with first publication rights granted to the journal. This is an open-access article distributed under the terms and conditions of the Creative Commons Attribution license (http://creativecommons.org/licenses/by/4.0/) 